\title{
How Mass Layoffs are related to lower Job Performance and OCB among Surviving Employees in Chile: An Investigation of the Essential Role of Psychological Contract
}

\author{
Sergio López Bohle \\ Department of Management, Faculty of Economics and Business, University of Santiago \\ Pontifical Catholic University of Chile \\ P. Matthijs Bal \\ University of Bath, United Kingdom \\ Paul G.W. Jansen \\ VU University Amsterdam, the Netherlands \\ Pedro I. Leiva \\ Department of Management, Faculty of Economics and Business, Universidad de Chile \\ Antonio Mladinic Alonso \\ Pontifical Catholic University of Chile, Santiago, Chile
}

Paper in press with International Journal of Human Resource Management

Correspondence should be addressed to: Matthijs Bal, University of Bath, School of Management, Bath BA2 7AY, United Kingdom. Email: p.m.bal@ bath.ac.uk; 0044-1225-383143. 


\section{How Mass Layoffs are related to lower Job Performance and OCB among Surviving Employees in Chile: An Investigation of the Essential Role of Psychological Contract ABSTRACT}

This study aimed to investigate how mass layoffs impact surviving employees in organizations. More specifically, this study ascertained the relationships between mass layoffs and employee work behaviors. It was theorized that mass layoffs will be negatively related to employee performance and OCB through its relationships with job insecurity and psychological contract breach. Moreover, it was expected that perceived manager support would buffer against the negative relations of contract breach with employee performance and OCB. A study among 615 employees in multiple Chilean organizations showed support for the hypotheses: job insecurity and psychological contract breach mediated the relationships between mass layoffs and employee performance and OCB. We also found moderating relationships of manager support, but the relations of breach with performance and OCB were particularly negative when manager support was high, indicating feelings of betrayal among high support employees in response to contract breach. Moreover, the relation of contract breach with performance was positive for lowsupport employees, and non-significant for high-support employees. Our study advances understanding of the processes underlying how mass layoffs influence employee behavior in the workplace, through introducing the psychological contract as a way of understanding the relationships.

Keywords: Mass Layoffs, Downsizing, Psychological Contract, Job Insecurity, Job Performance 
The economic recession that has started in 2008 in the US has had a global impact on organizations. While governments throughout the world have introduced various austerity measures, organizations are increasingly using downsizing and mass layoffs in response to economically difficult circumstances (Coile \& Levine, 2011; New York Times, 2014). To operate in highly competitive and globalized markets, more and more organizations try to cut as many costs while retaining profitability of the firm. One of the most prominently used ways of cost saving is to engage in downsizing and layoffs (Conway, Kiefer, Hartley, \& Briner, 2014; Datta, Guthrie, Basuil, \& Pandey, 2010). Organizations lay off employees in order to be able to survive while at the same time trying to retain productivity with less staff. Yet, there is increasing evidence of the negative side-effects of downsizing and layoffs on remaining employees in the organization (Datta et al., 2010). For instance, research has shown that surviving employees after layoffs may show lower performance levels (Grunberg, Anderson-Connolly, \& Greenberg, 2000). However, there is still little research available on the dynamics of how layoffs affect surviving employees in their work behaviors (Datta et al., 2010). More specifically, even though it is known that layoffs can have detrimental effects on well-being of surviving employees (Parker, Chmiel, \& Wall, 1997), there is not much known on how they affect work outcomes, and what organizations can do to alleviate these negative effects. For instance, the role of time since mass layoffs is yet under-researched, while it is likely that employees will feel more threatened when recently mass layoffs have taken place and therefore are less likely to perform and show organizational citizenship. However, the process through which the timing of mass layoffs in organizations impact the surviving employees is yet rather under-researched (Yu \& Park, 2006).

One of the explanations of the process underlying the effects of time since last mass layoffs on employees that has been presented is that layoffs put into doubt the psychological contracts of employees with their organizations even when these employees are not directly affected 
(Grunberg et al., 2000; Kim \& Choi, 2010). A mass-layoff will be perceived as a signal that the company does not uphold its share in the psychological contract anymore, that is a mass-layoff is likely to be perceived as a breach of the psychological contract. As a consequence, surviving employees in organizations may respond to layoffs by putting in less effort into their jobs and being less productive (Datta et al., 2010; Grunberg et al., 2000). Despite this notion, it is surprising that research thus far has largely ignored the role of psychological contracts with respect to the impact of layoffs on employees. Previous research has hinted at the relationships between layoffs and psychological contract breach. For instance, Arshad and Sparrow (2010) investigated psychological contract violation in the context of downsizing, but did not investigate whether employees are more likely to perceive their psychological contract as broken when they experienced more layoffs. Moreover, the review of Datta et al. (2010) explains that many studies on the individual-level outcomes of downsizing have used a psychological contract perspective, but there have been no studies that have actually measured the relations of layoffs with perceptions of contract breach.

Moreover, it is unknown through which process mass layoffs will have an impact on psychological contract breach. One of the reasons that has been provided is that mass layoffs induce strong feelings of insecurity among surviving employees (Adkins, Werbel, \& Farh, 2001). Since beliefs about job security form an important aspect of the psychological contract (De Cuyper \& De Witte, 2006), mass layoffs will be perceived to entail contract breach, which subsequently negatively relates to performance levels of surviving employees. Hence, we expect that mass layoffs impact employee performance through first influencing job insecurity and subsequently psychological contract breach.

Finally, the question is whether organizations can provide employees the means to buffer the negative effects of mass layoffs on employee behaviors. It has been suggested that providing 
support to employees is a powerful tool for organization to attenuate negative effects of downsizing and contract breaches (Brockner et al., 2004; Dulac, Coyle-Shapiro, Henderson, \& Wayne, 2008; Parker et al., 1997). It is therefore important to investigate whether support from the manager can be a buffer for employees against negative effects of mass layoffs. In sum, this study investigates both mediating and moderating processes in the relationships between time since mass layoffs and employee job performance.

The current study aims to elucidate the role of the psychological contract in employee responses to mass layoffs, and the relationships with subsequent employee performance. More specifically, we investigate whether time since the last mass layoff is related to perceptions of psychological contract breach, and we investigate the mediating role of job insecurity. Moreover, we ascertain the relationships of mass layoffs with employee performance and organizational citizenship behaviors (OCBs) through mediation of both perceived job insecurity and psychological contract breaches. Finally, our study will investigate the moderating role of manager support to employees in the relationships between contract breach and employee performance and OCB. Our research model is shown in Figure 1. The study is conducted in four organizations in Chile, and therefore also enriches understanding of the global impact of the economic recession on companies and responses from employees in those organizations. Through investigating the mediated relationships as well as the moderating impact of manager support, this study contributes to a further understanding of employee responses to mass layoffs. Our study is the first to investigate the role of psychological contracts in responses of employees to mass layoffs, and we show that the impact of mass layoffs on employee performance and OCBs can be best understood in a framework of increased job insecurity and perceptions of contract breach. Finally, our study contributes to research on psychological contracts, through showing that perceptions of contract breach can result from organizational actions that do not directly 
influence the employee, such as mass layoffs, but nonetheless will be perceived negatively by the employee, and consequently related to lower performance levels.

Insert Figure 1 about here

\section{Mass layoffs and job insecurity}

The recent global economic crisis has led to a rapid increase of downsizing, mass layoffs, and unemployment across countries worldwide (Conway et al., 2014; Markovits, Boer, \& Van Dick, 2014). The economic crisis has been perceived as a strong threat against the survival of organizations, and organizations in response to the economic crisis, have engaged in large downsizing operations and mass layoffs since the beginning of the crisis (Coile \& Levine, 2011). Employees have been made redundant due to mass layoffs, and there is ample research that shows the negative effects on people who are laid off on wellbeing and job attitudes (e.g., Blau, Petrucci, \& McClendon, 2012; Kim \& Choi, 2010). However, there is also an abundance of research that shows negative effects on survivors of layoffs (e.g., Allen, Freeman, Russell, Reizenstein, \& Rentz, 2001; Brockner et al., 2004; Grunberg et al., 2000; Kalimo, Taris, \& Schaufeli, 2003). It has been proposed that mass layoffs in organizations have profound psychological effects on employees who stay in the organization, the so-called survivors. For instance, a study of Brockner et al. (2004) showed that survivors of downsizing were less committed after downsizing had taken place. Moreover, other research has also shown that layoffs are associated with feelings of inequity as well as lower levels of well-being, including exhaustion and sickness (Grunberg et al., 2000; Kalimo et al., 2003). Hence, there is widespread evidence of the negative effects of layoffs on employees. However, still there is little knowledge on how layoffs influence employee perceptions, and the role of time with respect to layoffs. 
We argue that layoffs are associated with greater perceptions of job insecurity. In the current study we operationalize mass layoffs as the time since employees last experienced a mass layoff. The study from Allen et al. (2001) showed that it was especially the time that passed since the mass layoff that determined how satisfied and involved employees were in their jobs. Similarly, Datta et al. (2010) in their review discussed the issue of measurement of downsizing, and pointed towards the crucial role of time in relation to layoffs and employee responses. In line with these studies, we focus on the role of time passed since the last mass layoff. Research shows that time is an important aspect of mass layoffs: the more recent a layoff has been, the greater the impact on employees and the attitudes they hold towards their organization (Allen et al., 2001;

Kalimo et al., 2003). Theoretically, when mass layoffs have recently taken place in an organization, employees are expected to be influenced by those layoffs more profoundly. Employees may worry about whether in the near future new rounds of mass layoffs will follow, resulting in higher stress (Brockner et al., 2004). Moreover, the more recent mass layoffs have taken place in an organization, the more salient they will be in forming employee perceptions of their jobs. We expect that employees will be particularly sensitive towards perceptions of job insecurity immediately following mass layoffs. Job insecurity can be defined as the "perceived powerlessness to maintain desired continuity in a threatened job situation" (Greenhalgh \& Rosenblatt, 1984, p.438). It implies a perception among an employee that she/he is uncertain about the continuity of the job, and it is likely to result from layoffs in organizations. When organizations or units have recently engaged in mass layoffs, employees will be likely to have experienced emotional distress during the process (Kalimo et al., 2003). Research indeed shows that layoffs and resulting unemployment may have detrimental effects for both victims' wellbeing (Blau et al., 2012), as well as survivors (Boyd, Tuckey, \& Winefield, 2014; Kalimo et al., 2003). Hence, the effects of downsizing and layoffs are evident in both laid off employees and 
survivors, as their well-being may be negatively affected, and their stress levels and insecurity increase.

Moreover, survivors are likely to know colleagues who have been made redundant, and are uncertain whether in the near future next rounds of layoffs will follow, and therefore pessimistically anticipate future layoffs. Layoffs therefore create uncertainty among surviving employees, who may wonder whether their jobs will continue to exist (Brockner et al., 2004). Hence, it is likely that the more recently mass layoffs have occurred in the organization or unit, the more insecure employees will feel about the survival of their own jobs. Conversely, when there has been a long time since the last mass layoff in a company, employees may feel less threatened by the likelihood of losing their jobs (Allen et al. 2001). Moreover, when organizations did not engage in mass layoffs during the recent global economic crisis, employees will feel more secure about their jobs in the organization and trust their organization to survive during harsh economic times. Thus, we expect that time since the last mass layoff will be negatively related to job insecurity, indicating that more recent layoffs will be associated with higher job insecurity. Hypothesis 1 therefore is:

Hypothesis 1: Time since last mass layoff is negatively related to perceived job insecurity.

\section{Job insecurity and its relation with psychological contract breach}

While we expect that mass layoffs are related to higher perceptions of job insecurity, we propose that job insecurity is subsequently related to perceptions of psychological contract breach, and thus indirectly relates time since the last mass layoff with psychological contract breach. The psychological contract can be described as the perceived mutual obligations between an employee and the organization (Rousseau, 1995). According to Conway and Briner (2005), the psychological contract consists of both promises and obligations, but central to the concept is that the employee forms perceptions of both explicit and implicit obligations that both parties to the 
exchange have. Hence, psychological contracts are subjective in nature, and exist only in the eyes of the beholder (Rousseau, 1995). Instead of an actual agreement between employee and organization, the employee has various subjective perceptions about the implicit agreement between the employee and the organization. Psychological contracts become salient when employees evaluate whether their psychological contract has been fulfilled or breached (Morrison \& Robinson, 1997). Psychological contract breach is defined as the cognition that the employer has failed to fulfill one or more elements within the psychological contract (Morrison \& Robinson, 1997). Perceptions of job security have been cited frequently as being a part of the psychological contract of an employee with an organization (Adkins et al., 2001; De Vos, Buyens, \& Schalk, 2003). Hence, according to psychological contract theory, when employees perceive that their jobs have become more insecure as a result of mass layoffs in the organization, they will be increasingly likely to perceive their psychological contract as being breached by the organization. There is indeed evidence for the relation of job security with psychological contract breach. For instance, a study of De Cuyper and De Witte (2006) showed a negative relationship between job insecurity and psychological contract fulfillment. Hence, it is expected that high job insecurity will be positively associated with perception of psychological contract breach. Hypothesis 2 therefore is:

Hypothesis 2: job insecurity is positively related to psychological contract breach.

\section{Relations of contract breach with work outcomes}

In this study, we further propose that contract breach is negatively related to job performance and organizational citizenship behaviors. Consistent with prior work, we examine two types of work performance: job performance (in-role) and organizational citizenship behaviors (extra-role; OCBs; Organ, 1988; Williams and Anderson, 1991). The reactions of employees towards contract breach has been theorized primarily based on social exchange theory 
(Blau, 1964), and in particular the norm of reciprocity (Gouldner, 1960). According to social exchange theory, employees and employers engage in an exchange relationship in which each party reciprocates the other's contributions (Blau, 1964). Mutual obligations drive the behaviors of both parties over time, creating a bond between employee and organization. The norm of reciprocity (Gouldner, 1960) postulates that when employers do not fulfill their promises and obligations, the employee reciprocates by altering his or her contributions to the organization (e.g. by reducing their efforts and performance). Thus, psychological contract breach is expected to be negatively related to employee job performance. Moreover, when the organization fulfills its promised obligations, employees may be motivated and engage in discretionary behaviors, including increased effort and organizational citizenship (OCBs; Coyle-Shapiro, 2002; Turnley et al., 2003). Conversely, contract breach may adversely impact organizational citizenship. There is a vast amount of research that shows that psychological contract breach is related to lower job performance and OCB (Zhao, Wayne, Globkowski, \& Bravo, 2007). In sum and consistent with previous research, we expect that psychological contract breach is negatively related to job performance and organizational citizenship behaviors.

Hypothesis 3: psychological contract breach is negatively related to (a) job performance, and (b) organizational citizenship behavior.

\section{Mediation of job insecurity and contract breach in the relation of mass layoffs with employee performance}

The combination of the first three hypotheses implies that time since mass layoffs has an indirect, mediated effect on survivors' job performance and OCB through its relationships with job insecurity and psychological contract breach. As research has shown that mass layoffs may have an impact on employee performance (Datta et al., 2010; Grunberg et al., 2000), we expect this to be the case as well in our current study. The review by Datta et al. (2010) showed that 
there may be a general decline in employee performance after downsizing. However, many studies show inconsistent relationships; the study of Amabile and Conti (1999) found that while employee creativity was affected negatively in the long-term after downsizing, they also found that employee productivity, while initially decreasing after downsizing, stabilized over time. Moreover, the study of Yu and Park (2006) among downsizing Korean firms, found no effects of downsizing on employee productivity. Hence, there is a need to further investigate when and how mass layoffs lead to employee performance. This study therefore investigates both mediators and a moderating effect to the relation between layoffs and employee performance to advance understanding of how and when layoffs relate to lower employee performance.

More specifically, we expect mass layoffs to be related to employee performance, because it causes higher job insecurity, which subsequently relates to higher perceptions of contract breach. As a result of this, employees reciprocate contract breach by investing less effort into their jobs, and less helping behavior towards the organization. Even though there is some research on the role of layoffs in psychological contract perceptions (Arshad \& Sparrow, 2010; Kim \& Choi, 2010), there is no research that empirically links layoff experiences with perceptions of contract breach.

While employee performance may be a somewhat distal outcome of mass layoffs, our study aims to show the process of how mass layoffs have an indirect effect on employee performance. That is, we propose that mass layoffs are not directly related to employee performance, but rather via its relations with job insecurity and psychological contract breach. Meta-analytic work has shown that psychological contract breach is related to performance and OCB (and not necessarily vice versa), and research from De Cuyper and De Witte (2006) showed that job insecurity leads to psychological contract perceptions rather than psychological contract leading to job insecurity. 
In sum, our fourth hypothesis concerns the indirect, mediated relationships of mass layoffs with job performance and OCBs through job insecurity and contract breach. Hypothesis 4 is:

Hypothesis 4: the relationships between mass layoffs and (a) job performance and (b) organizational citizenship behaviors are sequentially mediated by job insecurity and psychological contract breach.

\section{Moderation of perceived manager support}

Finally, we expect that perceived manager support may buffer against the negative relationships of contract breach with employee performance. Previous research has shown that manager support may be important in buffering the impact of psychological contract breaches on work outcomes (Dulac et al., 2008; Robinson, 1996). When negative events happen in the workplace, managers and organizations can provide employees with the necessary resources and support to offset subsequent negative reactions (Bal, Chiaburu, \& Jansen, 2010a).

While mass layoffs may have a detrimental impact on employee performance (Datta et al., 2010), the question arises how organizations can take actions to prevent negative effects from occurring. We argue that managers may offer support to employees in order to alleviate the negative effects of perceptions of contract breach. While mass layoffs may sometimes seem unavoidable, and are initiated by organizations in an attempt to survive and to compete on a global market, employees may subsequently suffer from higher felt insecurity about the likelihood of the existence of their jobs in the future. Hence, perceptions of contract breach are unavoidable as employees respond to events happening in the wider context of a globalized labor market. However, when organizations offer their employees support, they may react less intensely to contract breaches. For employees who perceive that they receive much support from their managers, they may be likely to be more positively biased towards their organization, they feel more in control when negative events happen, and are less likely to blame their organization 
when they experience psychological contract breach (Bal et al., 2010a; Dulac et al., 2008). There is ample research that shows that support may buffer against the negative effects of stress, as it may bolster the ability to cope with demands and by providing solutions and potentially reducing the importance of the problem (Cohen \& Wills, 1985).

Dulac and colleagues (2008) found that organizational support buffered against the impact of contract breach on feelings of violation, and Robinson (1996) found that trust in management had similar buffering effects on the negative effects of contract breach on subsequent levels of trust. Drawing upon their arguments (Dulac et al., 2008; Robinson, 1996), it can be expected that when managers offer support to their employees, the latter will be less likely to be negatively affected by contract breach, and thus will uphold performance levels. Hence, we expected a buffer effect for manager support, as the resources that managers provide to employees may help them with coping with the negative consequences of contract breach perceptions. In sum, manager support to the employee may be an important buffer against the negative effects of contract breaches. Therefore, we expect that perceived manager support (Eisenberger et al., 1986) will moderate the relations of psychological contract breach with employee performance, such that the relations will be weaker when support is high. Hypothesis 5 therefore is:

Hypothesis 5: Manager support moderates the relations between psychological contract breach and (a) job performance and (b) organizational citizenship behavior, with stronger negative relationships for low manager support.

\section{METHODS}

\section{Participants and Procedure}

The study was conducted in Chile in three metal companies and one gas company. Human resource directors were approached to take part in the research, and once their approval has been received, both printed versions and an online link to the questionnaire was distributed among the 
employees in the organizations. Metal and gas companies were selected, because these industries were highly competitive and regular restructuring of firms were expected to have major impacts on employee motivation. The sample concentrated on workers who survived an organizational restructuring, pertaining to the metal mechanic industry and gas distribution services. The sample consisted of personnel from operational, administrative, professional and supervisory levels. $3.6 \%$ of the workers had basic elementary training as highest achieved educational level, $31.4 \%$ had completed high school studies, 35.5\% mention having taken courses in technical professional studies, $25.3 \%$ have completed university studies and $4.1 \%$ have attained post-graduate degrees. The mean organizational tenure was 8.84 years $(\mathrm{SD}=8.07)$, whose range varies from a minimum value of 7 months to a maximum value of 45.2 years of tenure with the company. The average length of job tenure was 6.01 years $(\mathrm{SD}=6.87)$, with a minimum value of one month and a maximum value of 47.2 years' stay. Finally, workers denote that the latest large-scale dismissal in their current company was 8 months ago $(\mathrm{SD}=7.50)$. To be included in the study, it was requested that workers had at least 6 months' work experience in their company in order to obtain reliable assessments of their performance. 615 employees ( $85 \%$ response rate) responded to the questionnaire that was sent out in January-March 2012. 28.4\% were women and $71.6 \%$ men, aged between 18 and 75 years and a mean age of 36.81 years $(S D=10.41)$. The difference in the distribution of men and women is characteristic of work in the metal and gas sector in Chile. As for the distribution by position held, $34 \%$ of participants worked on operator level, $24.6 \%$ worked in administrative positions, $16.5 \%$ occupied a professional position, $22.2 \%$ had a supervisory position, and $2.8 \%$ were assistant managers or managers.

\section{Measures}

Mass Layoffs was measured through asking the employee when they experienced the last mass layoff in their present company or unit (Kalimo et al., 2003). We focused on the time since 
the last mass layoff, as time has been referred to as the key indicator for the employee responses to mass layoffs (Allen et al., 2001; Datta et al., 2010). The questionnaire included a number of questions regarding to mass layoffs and whether employees had personal experiences with being laid off. These questions were introduced with a short description of what is referred to with a mass layoff, which is referred to as an organizational intervention or program where the contracts of a group of employees are terminated at the same time (Handwerker \& Mason, 2012). Hence, through this instruction, respondents had similar perceptions of what was meant with mass layoffs. Responses could be provided in years and months, and a total score was calculated indicating the time since the last mass layoff. Higher scores indicated that the last mass layoff has taken place longer ago. On average employees reported that it was 7.99 months $(\mathrm{SD}=7.50)$ since the last mass layoff. Since the distribution of the measure was skewed (as indicated by the large $\mathrm{SD}$, referring to some employees who experienced the last mass layoff a long time ago), we log transformed the variable, and used this log transformation in our analyses (not shown in Table 1). Six respondents $(1.1 \%)$ did not experience a mass layoff during their tenure with their organization, and hence, there is no indication that this has influenced the results, as $98.9 \%$ of the respondents has experienced a mass layoff during their tenure with their current organization.

All other measures were based on existing scales, which were translated in Spanish and back-translated in English, in line with the procedure of Brislin (1970). Answers could be provided on a 5-point Likert scale, ranging from 'totally disagree' to 'totally agree'. Job Insecurity $(\alpha=.79)$ was measured with the 4 -item scale of De Witte (2000). An example item is "I feel insecure about the future of my job". Psychological contract breach $(\alpha=.86)$ was measured with the 5-item global breach scale by Robinson and Morrison (2000), an example item being "My employer has broken many of its promises to me even though I've upheld my side of the deal". The scale has been found to be reliable and is often used in research on psychological 
contract breach (Robinson \& Morrison, 2000; Zhao et al., 2007). Perceived Manager Support ( $\alpha$ $=.90)$ was measured with an adapted 8-item scale from Eisenberger et al. (1986). While the original scale indicated support from the organization, the items were adapted such that they indicate support from the manager. An example of the scale is "My manager really cares about my well-being".

Job performance $(\alpha=.86)$ was measured with a 4-item scale of in-role performance based on Williams and Anderson (1991). The items we used were: "I adequately complete assigned duties", "I fulfill responsibilities specified in my job description", "I perform tasks that are expected of me", and "I meet formal performance requirements of the job". Self-reported job performance was the selected outcome, since comparable objective performance ratings across the organizations were not available. Moreover objective performance may be influenced by economic circumstances, through which a confounding effect may appear with mass layoffs. For instance, under economic difficult circumstances it is harder to maintain sales rates, while individual job performance may still be high. Moreover, while self-rated job performance may be a less objective indicator of performance than measures such as sales rates (Williams \& Anderson, 1991), the measure of job performance that is used in the current study indicates an assessment by the employee about their performance on the job (see e.g., Bal, Jansen, Van der Velde, De Lange, \& Rousseau, 2010b; De Vos et al., 2003). Subjective performance measures are valid for the current study. First, objective and subjective measures of performance are positively correlated and are similarly predicted by independent variables (Bommer, Johnson, Rich, Podsakoff, \& MacKenzie, 1995; Wall et al., 2004). Moreover, subordinate's perceptions of their own performance add to other ratings of performance (e.g., objective performance and supervisor rated performance), since they contribute in a unique way to the overall concept of performance (Conway \& Huffcutt, 1997). Moreover, Sturman and colleagues (2005), in their meta-analysis, 
showed that subjective ratings of performance are more reliable over time than objective ratings. Since our study focused on change of job performance over time, we deemed it appropriate to have subjective ratings of performance. $O C B(\alpha=.77)$ was measured with the 7-item OCB towards the organization scale from Williams and Anderson (1991), an example being "I give advance notice when I am unable to come to work".

\section{Control Variables}

In our analyses, we controlled for a range of factors that potentially could influence the outcome variables $(\mathrm{Ng} \&$ Feldman, 2010). Hence, we controlled for gender $(0=$ female, $1=$ male), age (in years), educational level ( 1 = primary education, 5 = graduate level at university), and work status $(0=$ fulltime, $1=$ part-time $)$. Moreover, we also controlled for the percentage of the family budget that one's income represented $(1=$ around $25 \%, 2=50 \%, 3=75 \%, 4=100 \%)$, to control for the extent to which the family was dependent upon the income of the employee. Finally, we controlled for work experience (in years), and personal layoff experience (indicated by how many times the employees had been dismissed during their career). Analyses

First, we conducted a Confirmatory Factor Analysis using Lisrel 8.80 (Jöreskog \& Sörbom, 2005) to test for the validity of the factor structure. A 5-factor model (job insecurity, contract breach, manager support, job performance, and OCB) obtained acceptable fit $\left(\chi^{2}=2002.45, d f=\right.$ $395, p<.001 ; \mathrm{RMSEA}=.08 ; \mathrm{CFI}=.94 ; \mathrm{SRMR}=.06)$, and fitted significantly better than a $2-$ factor model which included one factor for job insecurity, contract breach and manager support, and one for job performance and $\operatorname{OCB}\left(\chi^{2}=8473.82, d f=404, p<.001 ;\right.$ RMSEA = .18; CFI = .79; $\left.\operatorname{SRMR}=.13 ; \Delta \chi^{2}=6471.37, \Delta d f=9, p<.001\right)$, and a one-factor model $\left(\chi^{2}=12120.69, d f=405\right.$, $\left.p<.001 ; \mathrm{RMSEA}=.22 ; \mathrm{CFI}=.71 ; \mathrm{SRMR}=.17 ; \Delta \chi^{2}=10118.24, \Delta d f=10, p<.001\right) . \mathrm{We}$ also tested a model with paths from all of the items to an unmeasured latent factor to control for 
common method variance (Podsakoff, MacKenzie, \& Podsakoff, 2012). This model obtained a significant better fit than the 5-factor model $\left(\chi^{2}=1599.69, d f=360, p<.001\right.$; RMSEA $=.08$; CFI $\left.=.95 ; \mathrm{SRMR}=.04 ; \Delta \chi^{2}=402.76, \Delta d f=35, p<.001\right)$, but the model improvement was less than the $25 \%$ improvement suggested in previous research (Andrews, Kacmar, Blakely, \& Bucklew, 2008). The $25 \%$ model improvement indicates a reduction in Chi Square model fit of $25 \%$, as the model including the unmeasured latent factor is compared to the 5-factor model, would indicate the presence of common method bias (Andrews et al., 2008). Hence, we can conclude that even though common method variance is present in our data, it is not a pervasive problem. In sum, the CFA shows our factor structure is valid and that the variables represent statistically different constructs.

Moderated mediation analyses were conducted to test the hypotheses as summarized in Figure 1 (Hayes, 2012; Preacher, Rucker, \& Hayes, 2007). Moderated mediation analyses using bootstrap tests allow to simultaneously test the mediating and moderating effects under study. In line with recommendations of Hayes (2012) we used 5,000 bootstrap analyses to test the models. The independent variables were mean-centered to avoid multicollinearity (Cohen, Cohen, West, \& Aiken, 2003). First, we tested mediation models in which the relationships between mass layoffs, job insecurity, psychological contract breach, and job performance and OCB were ascertained. Indirect effects of mass layoffs on the outcome variables through job insecurity and contract breach were estimated with the recommended bias-corrected and accelerated bootstrapped confidence intervals (Preacher et al., 2007). Next, we tested models including moderated relationships of manager support with contract breach in relation to job performance and OCB. Significant relationships were plotted with slopes for one SD below and above the mean of the moderator (manager support).

\section{RESULTS}


Table 1 shows the correlations among the variables under study. Time since mass layoffs was negatively related to job insecurity $(r=-.13, p<.01)$. However, it was unrelated to the other constructs under study. Job insecurity was positively related to contract breach $(r=.17, p<.01)$, and contract breach was negatively related to manager support $(r=-.49, p<.01)$, job performance $(r=-.12, p<.01)$, and OCB $(r=-.17, p<.01)$. Table 2 shows the results of the bootstrap analyses for job insecurity, contract breach and job performance. Table 3 shows the results of the bootstrap regression analyses for OCB.

Insert Tables 1-3 about here

Hypothesis 1 predicted that mass layoffs are negatively related to job insecurity. Table 2 shows that time since mass layoffs were indeed negatively related to job insecurity $(b=-.0224$, $p<.001)$. Hence, the more time has passed since the last mass layoff, the less insecure the employee is about the job. Therefore, Hypothesis 1 is supported. Hypothesis 2 predicted that job insecurity is positively related to contract breach. The results in Table 2 supports $\mathrm{H} 2$, as job insecurity was indeed related to contract breach $(b=.1955, p<.001)$. Hence, the more insecure employees are about their jobs, the more they perceive their psychological contract has been broken. Hypothesis 3 predicted that contract breach was negatively related to job performance and OCB. Table 2 shows that contract breach was negatively related to job performance $(\mathrm{b}=-$ $.0824, p<.01)$. Table 3 shows that contract breach was negatively related to OCB $(b=-.1236$, $p<.01)$. Thus higher contract breach was associated with lower job performance and OCB. This fully supports hypothesis 3 .

Hypothesis 4 predicted that job security and psychological contract breach mediated the relationship between mass layoffs and job performance and OCB. We found no direct effects of 
mass layoffs on job performance or OCB (see Tables 2 and 3). Table 4 shows the total and indirect effects of mass layoffs on the outcome variables. The indirect effects of mass layoffs on job performance and OCB through sequential mediation of job insecurity and contract breach were both significant (on performance: $b=.0004$; Lower Level Confidence Interval $=.0001$, Upper Level Confidence Interval $=.0009 ;$ on OCB: $b=.0005$; Lower Level Confidence Interval $=.0002$, Upper Level Confidence Interval $=.0012)$. Hence, the mediating effect was significant for both outcomes. The relationships of mass layoffs with job performance and OCBs were mediated by job insecurity and contract breach. This fully supports hypothesis 4 .

Insert Table 4 about here

Hypothesis 5 predicted that manager support moderated the relationship between contract breach and job performance and OCB. Table 2 shows that manager support was positively related to job performance $(\mathrm{b}=.1842, p<.001)$, and Table 3 shows that manager support was positively related to OCB $(b=.1260, p<.001)$. Moreover, manager support moderated the relationships of contract breach with performance $(\mathrm{b}=-.1255, p<.001$; Table 2$)$ and OCB $(\mathrm{b}=-.0821, p<.01$; Table 3). Figure 2 shows the moderation effect in relation to job performance. The relationship of breach with performance was positive for low support-employees $(\mathrm{b}=.08, p<.05)$, while the relationship was negative for high support-employees $(b=-.10, p<.05)$. Figure 3 shows the interaction pattern for OCB. The relationship of contract breach with OCB was non-significant for low support-employees $(\mathrm{b}=-.01, n s)$, while being negative for high support-employees $(\mathrm{b}=$ $.13, p<.001)$. Further inspection of the interaction plot showed that employees with high support did not have lower OCB than employees with low support, indicating a mean-level difference between the two groups. These findings contradict hypothesis 5, as high manager support did not 
buffer the negative relationship of psychological contract breach with the outcomes. Instead, the relationships were more strongly negative among high support-employees.

We tested the improvement of this complete moderated mediation model with a mediationonly model, where manager support was only directly related to the outcomes, and did not include the moderation effect. The improvement in explained variance for the moderation effect was .03 (3\%) for job performance, while it was .02 (2\%) for OCBs. Finally, we have rerun our bootstrap analyses replacing age with organizational tenure as organizational tenure might have an influence on the outcomes. These analyses produced similar results as those presented above, with no differences in the significance of our estimates. Thus, the hypotheses tests show equal results, regardless whether we control for age or for organizational tenure.

Insert Figures 2-3 about here

\section{DISCUSSION}

This study aimed at investigating the mediating processes in the relationships between mass layoffs and surviving employees' work behaviors, including their job performance and OCBs. While previous research has shown that downsizing and mass layoffs are detrimental for employee performance (Datta et al., 2010), there is a need for research that shows how mass layoffs have an effect on survivor attitudes and behaviors, and which actions can be taken by organizations to decrease the negative effects arising from layoffs in organizations. This study shows that there is a sequential mediating relationship of mass layoffs with feelings of job insecurity and subsequent psychological contract breach perceptions, which relates to lower job performance and OCBs. When employees have recently experienced layoffs in their organizations, they may anticipate future layoffs in the organization, through which they will feel 
less secure about the future of their jobs. Hence, and in line with previous research (Adkins et al., 2001), mass layoffs are related to higher feelings of job insecurity among surviving employees. Subsequently, when employees feel insecure about their jobs, they are more likely to perceive their psychological contract as broken, since job security forms an important element in the psychological contract of employees with their organizations (Rousseau, 1995; Zhao et al., 2007). Psychological contract breach in its turn was negatively related with job performance and OCB, and additional mediation tests revealed that mass layoffs are related to job performance through its effects on subsequent job insecurity and psychological contract breach. Hence, this study shows the process through which mass layoffs may result in decreased employee efforts, due to negative feelings and social exchange processes (Bal et al., 2010b; Blau, 1964).

Moreover, this study also investigated the ways how organizations may alleviate the negative effects of mass layoffs on surviving employees. We hypothesized that following mass layoffs, employees may anticipate by feeling more insecure about their jobs, which could be interpreted as a breach of their psychological contract with their organization. But, when managers offer support to the employees, they may be likely to attribute this psychological contract breach to factors outside of the organization's control, through which they uphold their performance and OCBs (Bal et al., 2010a). However, our results indicated another pattern, with negative relations of contract breach with job performance and OCB among high-support employees, and a positive relationship with job performance was observed among low-support employees. These results contradicted our expectations, and inspection of the interaction patterns revealed that under conditions of high psychological contract breach, support did not matter. However, under conditions of low contract breach, job performance and OCB are higher for highsupport employees than for low-support employees. 
The negative relationship of contract breach with the outcomes for employees who receive high support can be explained using the intensifying-hypothesis (Bal et al., 2010a). According to Bal and colleagues (2010a), employees may respond to contract breach more severely when they have high-quality relationships with their organization and manager. This is because of a 'betrayal effect' (Bal et al., 2010a) that occurs when employees who have strong relationships feel betrayed when their organizations break their psychological contracts. Especially for employees who receive much support from their organizations, there is a lot at stake, and more to lose than employees who already are deprived of resources and support (Aselage \& Eisenberger, 2003). High support employees may also have higher expectations to be supported, and a contract breach may represent a significant event where employees also perceive a lack of protection and support from the manager. Hence, support acts as a signal from the organization that the employee is valued and will be protected, but psychological contract breach undoes this support.

Feelings of betrayal are not likely to occur among employees who have experienced mass layoffs in the distant past, but when employees experience their psychological contract as broken following mass layoffs and job insecurity, they may be likely to decrease their efforts put in the job, including performance and OCBs. However, when employees experience that their managers were supportive, they may see a discrepancy between the breach of their psychological contract, hence the unfavorable treatment by the organization, and the support they receive from their manager. Hence this discrepancy may be interpreted negatively by employees and hence reduce their efforts (Bal et al., 2010a).

In sum, employees who receive high support from their organizations may feel betrayed more than others when they perceive their psychological contracts as been broken, and therefore may react more intensely. For employees who received low support, we found that the relations of contract breach with the outcomes were non-significant or weak, and they did not respond 
strongly to these breaches. However, we found that for these employees, performance and OCB were already lower than those employees who received high support, and hence, contract breach has less impact on them. Although we can conclude that manager emotional support does not alleviate the negative effects of mass layoffs on work outcomes, it may be still relevant to offer support to employees since support has a main effect on performance and OCB. However, it may be the type of support that matters as well, since survivors in organizations may also benefit from more instrumental support (Boyd et al., 2014).

\section{Theoretical Implications}

Our study contributes to research on mass layoffs and downsizing but also to research on job insecurity and psychological contract breach. First, we contribute to understanding the process of how mass layoffs have an impact on work outcomes of surviving employees in organizations. We explained that there is a sequential process that starts when organizations initiate layoffs. First, employees are affected emotionally and cognitively, by feeling more insecure about their jobs, and realizing that their current jobs may be in danger (De Cuyper \& De Witte, 2006). Following these feelings of insecurity, employees perceive a breach in their psychological contract, and respond to this by decreasing their efforts in their jobs. Hence, surviving employees respond to mass layoffs through the negative feelings they have, and the social exchange processes following these negative feelings (Bal et al., 2010b). Hence, actions taken by organizations, such as mass layoffs, can be the start of a social exchange process, causing employees to respond with a decrease in their work efforts, ultimately leading to lower job performance and OCBs. This process can have profound implications, as we have shown that manager support did not act as a buffer against these negative effects. Hence, organizations need to do more in order to alleviate the negative effects resulting from mass layoffs on survivors. 
An important implication for research and theory on mass layoffs is the use of a psychological contract perspective. The more recent mass layoffs may have taken place, the more likely people see their psychological contract as broken because of increasing job insecurity. This connects research on downsizing (Datta et al., 2010) with research on employment relationships (Rousseau, 1995), and implies that organizational actions which not directly affect employees still have an important effect on the perceptions of the employment relationship, which explains why mass layoffs have an impact on employee performance even for survivors and even after some time. Hence, future research on the effects of mass layoffs on employee should incorporate an employment relationship perspective in understanding the effects.

This study also shows how perceptions of job insecurity and psychological contract breach can arise from events taking place in the organizations which not necessarily involves the employees themselves. Societal and organizational events, such as the crisis and subsequent mass layoffs (Datta et al., 2010; Markovits et al., 2014) may contribute to individual perceptions that one is no longer secure of the job, and perceptions that the psychological contract has been broken. Research on these antecedents can shed more light on the dynamics of these constructs as well as understanding of how they influence work outcomes, such as job performance and turnover. For instance psychological contract breach has been theorized as breach of the obligations between employee and organization (Rousseau, 1995; Zhao et al., 2007). These obligations may arise not only from explicit negotiation between an employee and the manager, but also from events taking place around the employee, such as layoffs. It is therefore important for future research on psychological contracts to also include a broader perspective, including events that take place outside of the immediate interaction between employee and manager, on the felt obligations between employee and organization.

\section{Limitations and Suggestions for Future Research}


This study also has some limitations. First, the paper was based on a cross-sectional study among employees in multiple Chilean organizations. Even though we took into account the role of time since the last mass layoff in our measures, we did not longitudinally study the relationships. Hence, even though our bootstrap analyses gave some indication, we cannot ascertain causality in our relationships. While our hypotheses were based on theory and previous research (e.g., Zhao et al., 2007), a limitation is that all measures were collected at the same time. Hence, it might be that the relationships were different in order, and we therefore suggest that future research also looks into the effects of mass layoffs over time and how they affect employees over longer periods of time. Second, our study was based on self-reports only. Because it was not possible to collect comparable performance ratings across the organizations, we deemed it appropriate to investigate self-rated performance. However, it may be the case that common method variance has affected our results, even though our analyses showed that the impact of common method variance was not large. We do suggest however, that future researchers also investigate the impact on objective work outcomes, including performance, withdrawal, and turnover. Furthermore, there may be differences between 'smaller' mass layoffs and 'larger' mass layoffs, which was not taken into account in our measure of layoffs. We deemed it appropriate to use this measure as it allowed us to test the relationships of time passed since the last mass layoff with the outcomes, and hence investigate the role of time more directly in relation to employee outcomes, as the more recent mass layoffs have occurred, the more likely employees will be emotionally affected (Allen et al., 2001). However, employees who have experienced larger mass layoffs, involving a larger number of employees may have been influenced to a greater extent. Future research therefore should also take into account not only how long ago mass layoffs have taken place, but also the nature of these layoffs, including the 
number of employees involved, and the percentage of employees that were involved during the mass layoff.

Since our focus of this study was on the time that passed since the last mass layoff, we aimed to obtain a wide range of responses and collected data in multiple organizations. While previous research (e.g., Allen et al., 2001; Datta et al., 2010) has focused on the effects of mass layoffs over shorter periods of time (e.g., less than two years; Allen et al., 2001), it is unknown whether mass layoffs that happened in a more distant past still affect employees in their perceptions of their work and their work behaviors. Since there is still no theory that explicitly addresses the time lags through which mass layoffs influence employee attitudes and behaviors, we have taken an empirical approach by specific investigation of time since the last mass layoff. The negative correlation of mass layoffs with job insecurity indeed indicates that the more recent mass layoffs have taken place, the stronger influence they have on employees' perceptions of job insecurity. A final limitation concerns the generalizability of the results. The study was conducted in four metal and gas companies in Chile, which operate in a highly competitive environment. The cultural and organizational context of Chile can be described as a culture with a moderate level of power distance, while having high levels of uncertainty avoidance and collectivism (Hofstede, 2001). Mass layoffs occur frequently in the competitive Chilean economy, which will result in employees also being more aware that mass layoffs may take place. However, in the Chilean context, people still have needs for legal systems that protect employees (Hofstede, 2001). Thus, even though the economic crisis has led to many companies laying off people, there may be large differences across countries and industries. We therefore suggest researchers to replicate the study in other contexts, in order to ascertain whether the relationships are stable across different situations.

\section{Practical Implications}


The current study shows that mass layoffs may have a profound impact on employees' work experiences and work behaviors. This study provides organizations and managers with further understanding of why mass layoffs may have detrimental effects on employee performance. Because more recent mass layoffs create job insecurity, employees are more likely to perceive their psychological contract to be broken, and reciprocate through withholding effort. Organizations have opportunities to intervene in this process, through a number of steps, as offering support to employees might not be enough to avoid negative consequences. First, organizations should rethink the necessity of mass layoffs as it not only affects employees who are made redundant, but also surviving employees negatively. For instance, opportunities to temporarily decrease pay costs across the organization may be a viable way of surviving economic hardship without laying off people. Second, when organizations do lay off people, it should focus on explicit renegotiating the psychological contract with surviving employees, for instance through offering real job security for people, and potentially offering other benefits to employees, such as programs to enhance employability, and facilities to re-educate, re-train, and re-think career opportunities for both direct victims and surviving employees, such that employees are not solely responsible for their own career, but that this responsibility is shared between the various parties. 


\section{REFERENCES}

Adkins, C.L., Werbel, J.D., \& Farh, J.L. (2001). A field study of job insecurity during a financial crisis. Group \& Organization Management, 26, 463-483.

Allen, T. D., Freeman, D. M., Russell, J. E., Reizenstein, R. C., \& Rentz, J. O. (2001). Survivor reactions to organizational downsizing: does time ease the pain? Journal of Occupational and Organizational psychology, 74, 145-164.

Amabile, T. M., \& Conti, R. (1999). Changes in the work environment for creativity during downsizing. Academy of Management Journal, 42, 630-640.

Andrews, M. C., Kacmar, K. M., Blakely, G. L., \& Bucklew, N. S. (2008). Group cohesion as an enhancement to the justice-affective commitment relationship. Group \& Organization Management, 33, 736-755.

Aselage, J., \& Eisenberger, R. (2003). Perceived organizational support and psychological contracts: A theoretical integration. Journal of Organizational Behavior, 24, 491-509.

Bal, P. M., Chiaburu, D. S., \& Jansen, P. G. (2010a). Psychological contract breach and work performance: is social exchange a buffer or an intensifier? Journal of Managerial Psychology, 25, 252-273.

Bal, P.M., Jansen, P.G.W., Van Der Velde, M.E., De Lange, A.H., \& Rousseau, D.M. (2010b). The role of future time perspective in psychological contracts: A study among older workers. Journal of Vocational Behavior, 76, 474-486.

Blau, G., Petrucci, T., \& McClendon, J. (2012). Effects of layoff victims' justice reactions and emotional responses on attitudes toward their previous employer. Career Development International, 17, 500-517.

Blau, P.M. (1964). Exchange and power in social life. New York: John Wiley and Sons. 
Bommer, W. H., Johnson, J. L., Rich, G. A., Podsakoff, P. M., \& MacKenzie, S. B. (1995). On the interchangeability of objective and subjective measures of employee performance: A meta-analysis. Personnel Psychology, 48, 587-605.

Boyd, C.M., Tuckey, M.R., \& Winefield, A.H. (2014). Perceived effects of organizational downsizing and staff cuts on the stress experience: The role of resources. Stress and Health, 30, 53-64.

Brislin, R. W. (1970). Back-translation for cross-cultural research. Journal of Cross-Cultural Psychology, 1, 185-216.

Brockner, J., Spreitzer, G., Mishra, A., Hochwarter, W., Pepper, L., \& Weinberg, J. (2004).

Perceived control as an antidote to the negative effects of layoffs on survivors' organizational commitment and job performance. Administrative Science Quarterly, 49, 76-100.

Cohen, J., Cohen, P., West, S. G., \& Aiken, L. S. (2003). Applied multiple regression/correlation analysis for the behavioural sciences (3rd ed.). Mahwah, NJ: Lawrence Erlbaum Associates, Inc.

Cohen, S., \& Wills, T. A. (1985). Stress, social support, and the buffering hypothesis. Psychological Bulletin, 98, 310-357.

Conway, J.M., \& Huffcutt, A.I. (1997). Psychometric properties of multisource performance ratings: A meta-analysis of subordinate, supervisor, peer, and self-ratings. Human Performance, 10, 331-360.

Conway, N., Kiefer, T., Hartley, J., \& Briner, R.B. (2014). Doing more with less? Employee reactions to psychological contract breach via target similarity or spillover during public sector organizational change. British Journal of Management, in press.

Coile, C.C., \& Levine, P.B. (2011). The market crash and mass layoffs: How the current economic crisis may affect retirement. The BE Journal of Economic Analysis \& Policy, 11. 
Coyle-Shapiro, J. A. M. (2002). A psychological contract perspective on organizational citizenship behavior. Journal of Organizational Behavior, 23, 927-946.

Datta, D. K., Guthrie, J. P., Basuil, D., \& Pandey, A. (2010). Causes and effects of employee downsizing: A review and synthesis. Journal of Management, 36, 281-348.

De Cuyper, N., \& De Witte, H. (2006). The impact of job insecurity and contract type on attitudes, well-being and behavioural reports: A psychological contract perspective. Journal of Occupational and Organizational Psychology, 79, 395-409.

De Vos, A., Buyens, D., \& Schalk, R. (2003). Psychological contract development during organizational socialization: Adaptation to reality and the role of reciprocity. Journal of Organizational Behavior, 24, 537-559.

Dulac, T., Coyle-Shapiro, J. A., Henderson, D. J., \& Wayne, S. J. (2008). Not all responses to breach are the same: The interconnection of social exchange and psychological contract processes in organizations. Academy of Management Journal, 51, 1079-1098.

Gouldner, A. W. (1960). The norm of reciprocity: A preliminary statement. American Sociological Review, 25, 161-178.

Greenhalgh, L., \& Rosenblatt, Z. (1984). Job insecurity: Toward conceptual clarity. Academy of Management Review, 9, 438-448.

Grunberg, L., Anderson-Connolly, R., \& Greenberg, E. S. (2000). Surviving layoffs the effects on organizational commitment and job performance. Work and Occupations, 27, 7-31.

Handwerker, E. W., \& Mason, L. G. (2012). Which Layoffs-And Which Laid-off Workers-Are in the Mass Layoff Statistics. Monthly Labor Review, 135, 17-27.

Hayes, A. F. (2012). PROCESS: A versatile computational tool for observed variable mediation, moderation, and conditional process modeling. Manuscript submitted for publication. 
Hofstede, G. (2001). Culture's consequences: comparing values, behaviors, institutions and organizations across nations. Thousand Oaks, CA: Sage.

Joreskog, K., \& Sorbom, D. (2005). LISREL 8.72. Chicago: Scientific Software International. Kalimo, R., Taris, T.W., \& Schaufeli, W.B. (2003). The effects of past and anticipated future downsizing on survivor well-being: an equity perspective. Journal of Occupational Health Psychology, 8, 91-109.

Kim, M.S., \& Choi, J.N. (2010). Layoff victim's employment relationship with a new employer in Korea: effects of unmet tenure expectations on trust and psychological contract. The International Journal of Human Resource Management, 21, 781-798.

Markovits, Y., Boer, D., \& van Dick, R. (2014). Economic crisis and the employee: The effects of economic crisis on employee job satisfaction, commitment, and self-regulation. European Management Journal, 32, 413-422.

Morrison, E.W., \& Robinson, S.L. (1997). When employees feel betrayed: A model of how psychological contract violation develops. Academy of management Review, 22, 226-256.

New York Times (2014). http://topics.nytimes.com/top/reference/timestopics/subjects/l

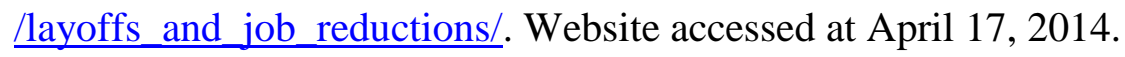

Ng, T.W., \& Feldman, D.C. (2010). The relationships of age with job attitudes: a meta-analysis. Personnel Psychology, 63, 677-718.

Organ, D.W. (1988). Organizational citizenship behavior: The good soldier syndrome. Lexington Books/DC Heath and Com.

Parker, S.K., Chmiel, N., \& Wall, T.D. (1997). Work characteristics and employee well-being within a context of strategic downsizing. Journal of Occupational Health Psychology, 2, 289-303. 
Podsakoff, P.M., MacKenzie, S.B., \& Podsakoff, N.P. (2012). Sources of method bias in social science research and recommendations on how to control it. Annual Review of Psychology, 63, 539-569.

Preacher, K.J., Rucker, D.D., \& Hayes, A.F. (2007). Addressing moderated mediation hypotheses: Theory, methods, and prescriptions. Multivariate behavioral research, 42, 185227.

Robinson, S. L. (1996). Trust and breach of the psychological contract. Administrative Science Quarterly, 41, 574-599.

Robinson, S.L., \& Morrison, E.W. (2000). The development of psychological contract breach and violation: A longitudinal study. Journal of organizational Behavior, 21, 525-546.

Rousseau, D.M. (1995). Psychological contracts in organizations: Understanding written and unwritten agreements. Thousand Oaks, CA: Sage Publishers.

Sturman, M.C., Cheramie, R.A., \& Cashen, L.H. (2005). The impact of job complexity and performance measurement on the temporal consistency, stability, and test-retest reliability of employee job performance ratings. Journal of Applied Psychology, 90, 269.

Turnley, W.H., Bolino, M.C., Lester, S.W., \& Bloodgood, J.M. (2003). The impact of psychological contract fulfillment on the performance of in-role and organizational citizenship behaviors. Journal of Management, 29, 187-206.

Wall, T.D., Michie, J., Patterson, M., Wood, S. J., Sheehan, M., Clegg, C.W., \& West, M. (2004). On the validity of subjective measures of company performance. Personnel Psychology, 57, 95-118.

Williams, L.J., \& Anderson, S.E. (1991). Job satisfaction and organizational commitment as predictors of organizational citizenship and in-role behaviors. Journal of Management, 17, 601-617. 
Yu, G. C., \& Park, J. S. (2006). The effect of downsizing on the financial performance and employee productivity of Korean firms. International Journal of Manpower, 27, 230-250.

Zhao, H., Wayne, S.J., Glibkowski, B.C., \& Bravo, J. (2007). The impact of psychological contract breach on work-related outcomes: a meta-analysis. Personnel Psychology, 60, 647680. 
Table 1: Means, standard deviations, reliabilities and correlations of the study variables.

\begin{tabular}{|c|c|c|c|c|c|c|c|c|c|c|c|c|c|c|c|c|}
\hline & Variable & $M$ & $S D$ & 1 & 2 & 3 & 4 & 5 & 6 & 7 & 8 & 9 & 10 & 11 & 12 & 13 \\
\hline 1 & Gender & .72 & -- & -- & & & & & & & & & & & & \\
\hline 2 & Age & 36.81 & 10.41 & .05 & -- & & & & & & & & & & & \\
\hline 3 & Education & 2.95 & .94 & $-.17 * *$ & $-.15 * *$ & -- & & & & & & & & & & \\
\hline 4 & Work Status & .04 & -- & $.13 * *$ & $-.09 *$ & $-.12 * *$ & -- & & & & & & & & & \\
\hline 5 & Family Income & 2.99 & 1.00 & $.24 * *$ & $.34 * *$ & $-.10 *$ & .02 & -- & & & & & & & & \\
\hline 6 & Work Experience & 15.44 & 9.98 & .06 & $.88^{* *}$ & $-.27 * *$ & -.05 & $.31 * *$ & -- & & & & & & & \\
\hline 7 & Lay Off Experience & .56 & 1.01 & $.12 * *$ & $.13 * *$ & $-.09 *$ & .05 & $.09 *$ & $.17 * *$ & -- & & & & & & \\
\hline 8 & $\begin{array}{l}\text { Time since last Mass } \\
\text { Layoff }\end{array}$ & 7.99 & 7.50 & $.24 * *$ & -.02 & $-.28 * *$ & -.04 & .00 & .04 & .02 & -- & & & & & \\
\hline 9 & Job Insecurity & 2.62 & .88 & .06 & $.08 *$ & $-.10 *$ & $.09 *$ & $.13 * *$ & $.08 *$ & $.10^{*}$ & $-.13 * *$ & .79 & & & & \\
\hline 10 & PC Breach & 2.28 & .80 & -.02 & -.03 & .07 & -.05 & -.01 & -.02 & .01 & -.09 & $.17 * *$ & .86 & & & \\
\hline 11 & Manager Support & 3.94 & .73 & .02 & -.05 & .02 & .01 & -.02 & -.08 & .00 & .08 & $-.26 * *$ & $-.49 * *$ & .90 & & \\
\hline 12 & Job Performance & 4.38 & .48 & -.06 & .07 & -.07 & -.01 & .05 & .05 & -.02 & -.07 & -.02 & $-.12 * *$ & $.20 * *$ & .86 & \\
\hline 13 & $\mathrm{OCB}$ & 4.16 & .47 & -.06 & $.11 * *$ & -.01 & -.07 & .03 & $.09 *$ & .03 & .01 & -.03 & $-.17 * *$ & $.19 * *$ & $.42 * *$ & .77 \\
\hline
\end{tabular}

Note. Reliabilities are reported along the diagonal. $N=615 .{ }^{*} p<.05,{ }^{* *} p<.01$. Time since last mass layoff is measured in months. 
Table 2: Estimates for Bootstrap Analyses for Job Performance.

\begin{tabular}{|c|c|c|c|c|}
\hline & \multicolumn{4}{|c|}{ Dependent Variables } \\
\hline & Job Insecurity & PC Breach & Job Performance & Job Performance \\
\hline & Model 1 & Model 2 & Model 3 & Model 4 \\
\hline & b (s.e.) & b (s.e.) & b (s.e.) & b (s.e.) \\
\hline \multicolumn{5}{|l|}{ Control Variables } \\
\hline Gender & $.1027(.0935)$ & $-.0167(.0935)$ & $-.0695(.0541)$ & $-.0696(.0526)$ \\
\hline Age & .0138(.0088) & $-.0096(.0083)$ & $.0067(.0050)$ & $.0053(.0049)$ \\
\hline Education & $-.0959(.0470)^{*}$ & $.0934(.0446)^{*}$ & $-.0583(.0269)^{*}$ & $-.0633(.0261)^{*}$ \\
\hline Work Status & .2552 (.2074) & $-.1761(.1963)$ & $-.1311(.1180)$ & $-.1306(.1144)$ \\
\hline Family Income & $.0682(.0432)$ & $.0029(.0409)$ & $.0151(.0246)$ & $.0089(.0238)$ \\
\hline Work Experience & $-.0109(.0093)$ & $.0040(.0088)$ & $-.0060(.0053)$ & $-.0040(.0052)$ \\
\hline Lay Off Experience & $.0538(.0395)$ & $-.0052(.0374)$ & $-.0019(.0225)$ & $-.0051(.0218)$ \\
\hline \multicolumn{5}{|l|}{ Independent Variables } \\
\hline Time since Last Mass & $-.0224(.0056)^{* * *}$ & $-.0017(.0054)$ & $-.0048(.0033)$ & $-.0054(.0032)$ \\
\hline $\begin{array}{l}\text { Layoff } \\
\text { Job Insecurity }\end{array}$ & & & & _077 (0270) \\
\hline Job Insecurity & & $.1955(.0444)^{* * *}$ & $-.0226(.0272)$ & $-.0077(.0270)$ \\
\hline PC Breach & & & $-.0824(.0282) * *$ & $-.0076(.0312)$ \\
\hline Manager Support & & & & $.1842(.0370)^{* * *}$ \\
\hline \multicolumn{5}{|l|}{ Interaction Term } \\
\hline PCB * Manager Support & & & & $-.1255(.0367)^{* * *}$ \\
\hline $\mathrm{R}^{2}$ & .07 & .06 & .05 & .11 \\
\hline F & $4.14 * * *$ & $3.12 * *$ & $2.14^{*}$ & $4.44 * * *$ \\
\hline
\end{tabular}

Note. ${ }^{*} p<.05,{ }^{* *} p<.01,{ }^{* * *} p<.001$. 
Table 3: Estimates for Bootstrap Analyses for OCB.

\begin{tabular}{|c|c|c|}
\hline & \multicolumn{2}{|c|}{ Dependent Variables } \\
\hline & OCB & OCB \\
\hline & Model 5 & Model 6 \\
\hline & b (s.e.) & b (s.e.) \\
\hline \multicolumn{3}{|l|}{ Control Variables } \\
\hline Gender & $-.1144(.0507)^{*}$ & $-.1134(.0501)^{*}$ \\
\hline Age & $.0017(.0047)$ & $.0009(.0046)$ \\
\hline Education & $-.0138(.0253)$ & $-.0169(.0249)$ \\
\hline Work Status & $-.1468(.1107)$ & $-.1469(.1091)$ \\
\hline Family Income & $.0486(.0231)$ & $.0439(.0228)$ \\
\hline Work Experience & $.0012(.0050)$ & $.0024(.0049)$ \\
\hline Lay Off Experience & $.0091(.0211)$ & $.0067(.0208)$ \\
\hline \multicolumn{3}{|l|}{ Independent Variables } \\
\hline Time since Last Mass & .0027(.0031) & $.0023(.0030)$ \\
\hline Layoff & & \\
\hline Job Insecurity & -0093 (.0255) & $.0201(.0258)$ \\
\hline PC Breach & $-.1236(.0265)^{* *}$ & $-.0725(.0297)^{*}$ \\
\hline Manager Support & & $.1260(.0350)^{* * *}$ \\
\hline \multicolumn{3}{|l|}{ Interaction Term } \\
\hline PCB * Manager Support & & $-.0821(.0357)^{* *}$ \\
\hline $\mathrm{R}^{2}$ & .08 & .11 \\
\hline $\mathrm{F}$ & $3.91 * * *$ & 4.66 *** \\
\hline
\end{tabular}

Note. ${ }^{*} p<.05,{ }^{* *} p<.01,{ }^{* * *} p<.001$. 
Table 4: Total and Indirect Effects Predicting the Outcomes

\begin{tabular}{llc}
\hline & \multicolumn{2}{c}{ Dependent Variables } \\
\hline Total Effect & $\begin{array}{c}\text { Job Performance } \\
\text { (Confidence } \\
\text { Interval) }\end{array}$ & $\begin{array}{c}\text { OCB (Confidence } \\
\text { Interval) }\end{array}$ \\
Time since last Mass Layoff $\rightarrow$ Job Performance & .0010 \\
Indirect Effect & {$[-.0004 ; .0028]$} & \\
Time since last Mass Layoff $\rightarrow$ Job Insecurity $\rightarrow$ Contract Breach $\rightarrow$ & .0004 \\
Job Performance & {$[.0001 ; .0009]$} & \\
Total Effect & & .0005 \\
Time since last Mass Layoff $\rightarrow$ OCB & & {$[-.0014 ; .0025]$} \\
Indirect Effect & & .0005 \\
Time since last Mass Layoff $\rightarrow$ Job Insecurity $\rightarrow$ Contract Breach $\rightarrow$ & & {$[.0002 ; .0012]$} \\
OCB & & \\
\hline
\end{tabular}

Note. ${ }^{*} p<.05,{ }^{* *} p<.01,{ }^{* * *} p<.001$. 
Figure 1: Research Model of the Current Study

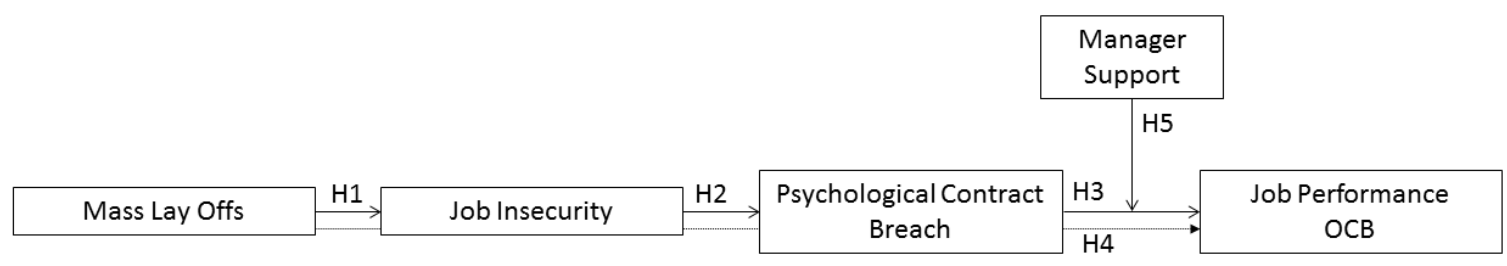


Figure 2: The interaction effect between psychological contract breach and manager support in relation to job performance.

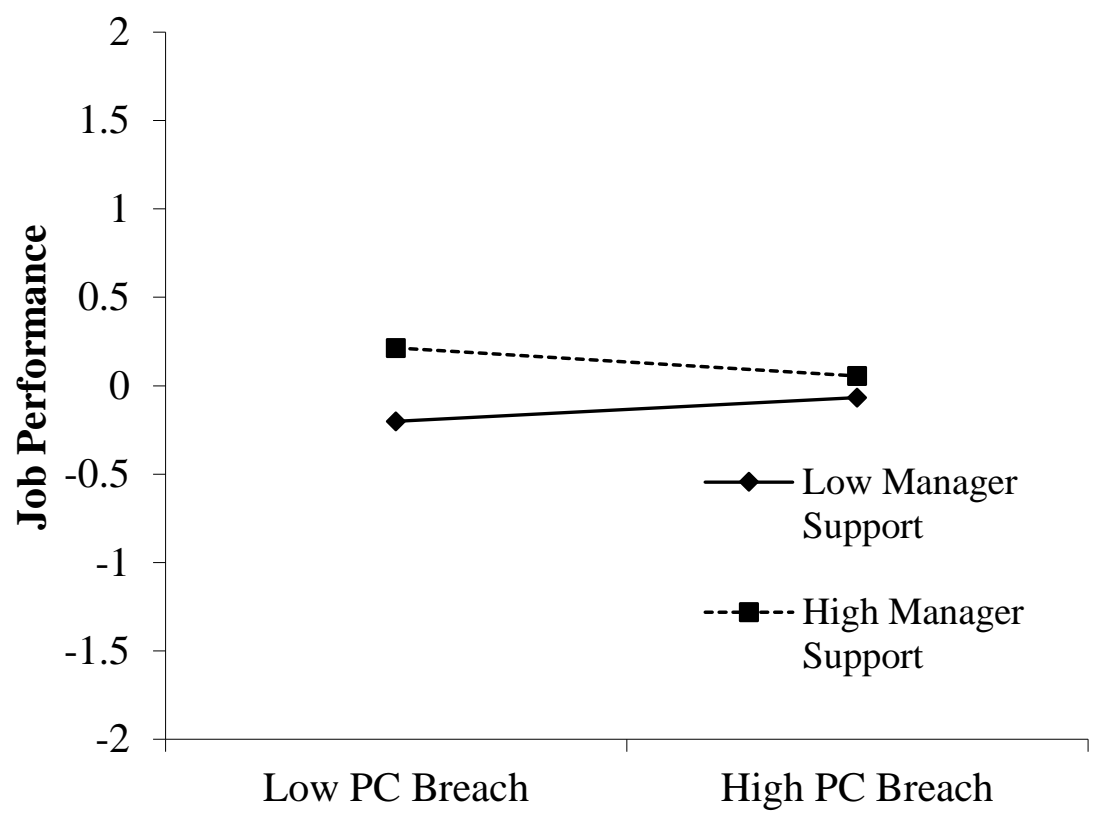


Figure 3: The interaction effect between psychological contract breach and manager support in relation to $\mathrm{OCB}$.

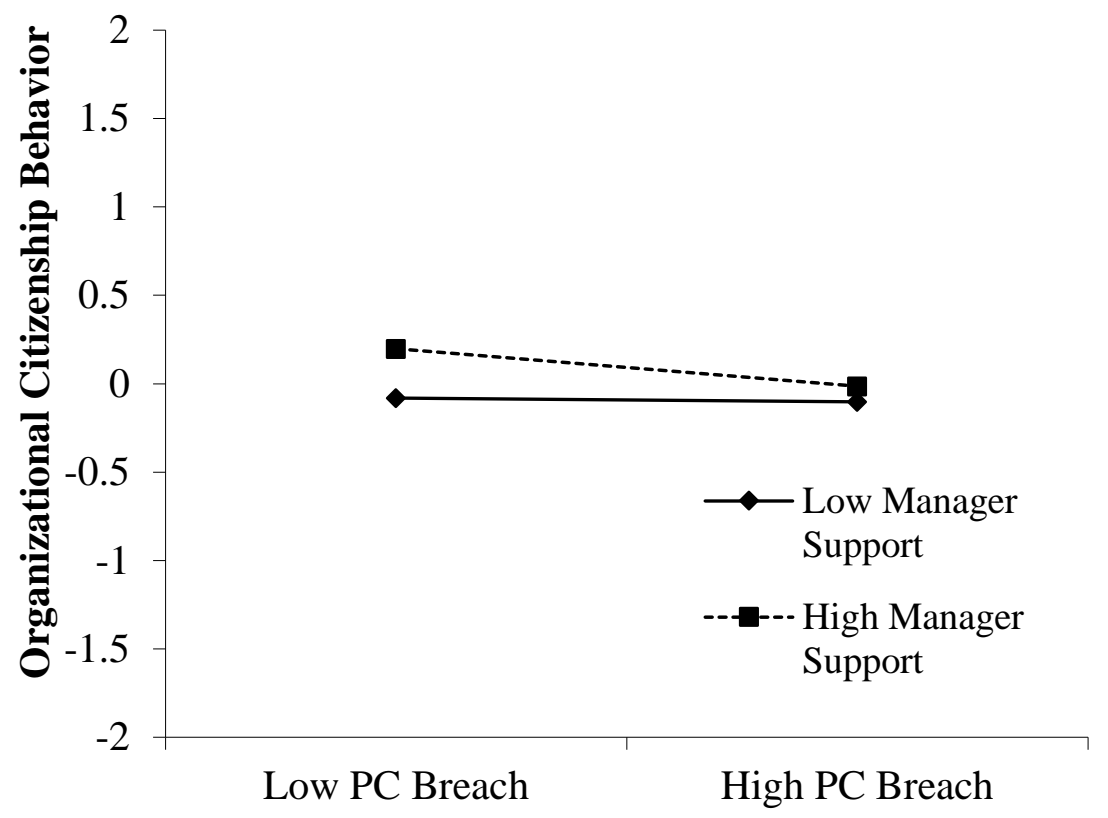

